\title{
Agency-Linked Risk Management with Ownership and Board Sub-Committee Governance: Evidence from an OECD Economy
}

\author{
Omar Al Farooque
}

Citation: Farooque, Omar Al. 2021 Agency-Linked Risk Management with Ownership and Board Sub-Committee Governance: Evidence from an OECD Economy. Journal of Risk and Financial Management 14: 472. https:// doi.org/10.3390/jrfm14100472

Academic Editor: Thanasis Stengos

Received: 25 August 2021

Accepted: 1 October 2021

Published: 7 October 2021

Publisher's Note: MDPI stays neutral with regard to jurisdictional claims in published maps and institutional affiliations.

Copyright: (C) 2021 by the author. Licensee MDPI, Basel, Switzerland. This article is an open access article distributed under the terms and conditions of the Creative Commons Attribution (CC BY) license (https:// creativecommons.org/licenses/by/ $4.0 /)$.
UNE Business School, University of New England, Armidale, NSW 2351, Australia; ofarooqu@une.edu.au

\begin{abstract}
From a risk management perspective, this study examines the role of ownership and board sub-committee governance on direct measures of agency costs in a small OECD economy-New Zealand. Using Logistic and OLS regression approaches, two proxies of direct agency costs are tested on a pooled sample of 466 firm-year observations ranging from 2012 to 2018 . The study provides evidence that insider ownership concentration outperforms outsider ownership concentration in constraining agency costs. Moreover, audit committee independence can also effectively deter agency costs. These findings suggest that both insider ownership concentration and audit committee structure are important risk management mitigating factor for deterring agency costs in New Zealand companies.
\end{abstract}

Keywords: risk management; direct measures of agency costs; ownership concentration; board sub-committee structure; New Zealand

JEL Classification: G30; G34

\section{Introduction}

We investigate the role of ownership and board sub-committee governance on 'direct' measures of agency costs among publicly listed companies in New Zealand (hereafter, NZ) from a risk management viewpoint. The study is motivated by the fact that no prior studies examine this relationship when there are considerable debates and scepticisms in the literature regarding the performance, accountability and commitment of rational behaviour of the board of director sub-committees (Wintoki 2007) and whether independent directors always fulfil their duties as expected. Liu et al. (2016) argue that the effectiveness of independent directors has long been discussed and disputed, yet the regulators have high expectations on independent directors, as evidenced in the Sarbanes-Oxley Act's highlighting of independence directors' role in the boards and audit committees. In this paper, we focus on alternative ownership concentration and audit committee variables' relationships with agency costs in a relatively small stock market in OECD countries-New Zealand, which is relatively under-researched, to reinforcing monitoring and complementing the role of board and ownership in deterring agency costs. Because audit committee members are independent outside directors and financially literate with auditing knowledge, they are more likely to make expert judgments than other board members. As such, an independent audit committee is more committed in restraining agency costs and their members ought to be averse to unethical practices. In addition, both insider and outsider ownership concentration can play vital roles in restraining agency costs from the viewpoints of incentive alignment and monitoring.

The agency problem is underpinned by the divorce of ownership and control within firms and the non-alignment of interests between controlling and non-controlling parties. A vast majority of literature documents that agency problems may arise between principals (owners) and agents (managers) (Type I) (Berle and Means 1932; Jensen and Meckling 1976; Fama and Jensen 1983), and between principals (controlling shareholders) and principals 
(minority shareholders) (Type II) (Shleifer and Vishny 1986; Shleifer and Vishny 1997; La Porta et al. 2000; Villalonga and Amit 2006). Both types typically incur huge costs to corporate firms involving the controller's private benefits that are detrimental to the value of the firm. Shleifer and Vishny (1997) contend that the private benefits from control right (opportunism) are frequent manifestations of the agency problem that needs to be addressed. To mitigate agency costs, significant monitoring mechanisms, such as corporate governance instruments (i.e., a variety of internal and external mechanisms) are installed within the firm (Shleifer and Vishny 1986). However, regardless of stages of economic development in most of the countries, firms rely more on internal governance mechanisms (such as ownership structure, board of director sub-committees, and compensation) than external mechanisms to deal with agency costs.

Reflecting on the increased role of internal corporate governance, a large part of literature contains analysis of corporate board and ownership as the dominant mechanisms in controlling 'direct' measures of agency costs (Ang et al. 2000; Brennan 2006; Henry 2010; Wellalage and Locke 2011; Rashid 2015; Vijayakumaran 2019), whereas other studies report the roles of managerial compensation, CEO-chair duality and tenure and nomination committee on agency costs (Henry 2010; Florackis 2008; McKnight and Weir 2009). While only a limited number of studies have presented evidence on the direct effects of ownership and board sub-committee governance mechanisms on agency costs. These studies examine the relationship between corporate board/ownership and direct measures of agency costs in different jurisdictions, the role of audit committee structure has not yet been analysed in the literature in a consistent empirical fashion. The current study is unique in its choice of ownership concentration as well as audit committee variables in contracting agency costs from a risk management position. It aims to fill this gap in the empirical literature and contribute to the management literature.

Our paper differs from prior research and contributes to knowledge in a number of ways. First, this study is the first to measure 'direct' agency costs of NZ listed companies that examines whether ownership concentration and audit committee structure variables are deterring or aggravating this cost. No previous study in the literature has attempted to investigate the effect of alternative ownership concentration and audit committees on the direct measures of agency cost. In addition, no previous study has attempted to measure agency costs in the NZ context, although a recent study was conducted into unlisted small firms (Wellalage and Locke 2011). Unlike prior studies on direct measurement of agency costs, the current study employs audit committee independence and size in order to observe their agency deterrent effects. Audit committee size and composition (independence) have not been tested in the literature ${ }^{1}$, although the audit committee is actively involved in overseeing financial reporting and related audit oversight functions, rather than the board, and maintains ethical principles. As such, it can be argued that audit committee has an upper hand over the board in alleviating direct measures of agency cost.

Second, NZ is an OECD nation with a relatively small stock market and small number of companies. As an Anglo-Saxon nation, NZ-based companies are more prone to Type I agency problems, but for a high level of ownership concentration, ${ }^{2}$ the very existence of Type II agency problems is also more likely to occur in NZ companies than in those of other OECD countries. To date, much of the empirical research on 'direct' measurement of agency costs and its relationship with corporate governance has focused on the US, UK and Australian companies only. NZ provides an interesting setting from that found in other OECD jurisdictions, where high levels of both internal and external concentrated ownership remains a unique characteristic in NZ market. NZ exhibits a distinctive nature of high ownership compatible to Asian countries, which provides the opportunity to test new hypotheses that are not testable in other OECD countries, and this could lead to different, but interesting, findings from that of the prior literature. Again, ownership concentration is the central issue in the theory of corporate governance as well as understanding the root cause of agency costs (Shleifer and Vishny 1997). Therefore, mutually exclusive internal and external ownership concentration variables are used in this study to examine whether 
they can reduce or exacerbate agency costs where regulation is less stringent, enforcement is weaker, and protection of non-controlling shareholders are less as compared to other OECD countries (Hossain et al. 2001).

Third, with the introduction of 'Corporate Governance Codes and Principles' and subsequent amendments, following other OECD countries, it is of interest to observe the progress in mitigating agency costs in NZ companies. Especially, the role of audit committees and ownership concentration in dealing with direct measures of agency cost along with other board related variables is of particular interest.

The remainder of the paper is structured as follows: Section 2 reviews prior studies and develops the hypotheses; Section 3 specifies data and regression models tested; Section 4 presents the results of empirical testing and Section 5 discusses these results and provides concluding remarks.

\section{Literature and Hypotheses Development}

Empirical studies have focused on different control mechanisms (such as, ownership and internal corporate governance, financing policy and external governance) and firm performance outcomes in contributing to lowering agency costs. Henry (2010) provides these different approaches highlighted in the literature as attributable to mitigation of agency costs. The agency models identified in these studies adopt a number of governance mechanisms to maximise firm value by aligning the interests of agents and principals and reducing agency costs. Despite valuable insights, these subsets of literature are not directly relevant to measuring the proxies for undesirable agency costs, or to factors influencing the levels of agency costs including internal monitoring instruments. To date, relatively few studies undertake a direct measurement of agency cost and its determinants in a firm's setting focusing on the role of ownership concentration, internal governance and firmspecific variables. Even though only a limited number of studies explore the relationship between direct measures of agency costs and governance mechanisms, there is evidence that internal governance mechanisms play a significant effect in alleviating agency costs.

Ang et al. (2000) undertook the first study to directly tackle the measurement (or proxy for) of agency costs (that is, total sales to total assets ratio and total operating expense to total sales) and determinants of agency costs in non-listed US small firms. Consistent with the convergence of interest hypothesis (Jensen 1993), they find a positive relationship between managerial ownership and asset turnover ratio, and a negative relationship between managerial ownership and expense ratio, that is insider ownership is found to be inversely related to agency costs. They also point out that debt and external bank monitoring play a role in alleviating agency costs, while the number of shareholders and non-owner managers plays an aggravating role. Several studies extend the work of Ang et al. (2000) in different countries and with different data periods (such as, (Doukas et al. 2000, 2005; Singh and Davidson III 2003; Chen et al. 2011) on the US, (Florackis 2008) and (McKnight and Weir 2009) on the UK, (Fleming et al. 2005) and (Henry 2010) on Australia, (Wellalage and Locke 2011) on New Zealand, (Moez 2018) on French, (Noravesh et al. 2009) on Iran, (Ibrahim and Samad 2011) on Malaysia, Rashid (2015) on Bangladesh and (Vijayakumaran 2019) on China).

Singh and Davidson III (2003) investigate the same measures in US large-listed firms by measuring agency costs (total sales to total assets ratio and selling, general and administrative expenses to total sales) and highlighting the role of ownership, board and debt in alleviating agency costs. Their evidence shows insider ownership and small boards help alleviate agency costs, while debt has an aggravating role; outside block ownership may have a limited effect and independent board members have no effect on reducing agency costs. Again, both Doukas et al. (2000) and Doukas et al. (2005) examine agency cost determinants for listed US firms and find that greater analyst following can reduce agency costs, but not institutional ownership, while non-linear relations exist between insider ownership, leverage and the levels of agency costs. Florackis (2008) also examines the impact of ownership, board, managerial compensation and capital structure on agency 
costs (i.e., total sales to total assets ratio and selling, general and administrative expenses to total sales) in large UK-listed firms, paying particular attention to the role of growth opportunities. Findings of the study reveal consistent results in alleviating agency costs by managerial ownership, concentrated ownership, debt and compensation. Florackis (2008) also argues that the influence of internal mechanisms on agency costs may vary with firm growth opportunities in the UK. McKnight and Weir (2009) investigate the impact of ownership and governance variables on three proxies of agency costs (total sales to total assets ratio, interaction of free cash flows and growth prospects and the number of acquisitions) in large UK-listed companies. Applying a range of analytical techniques, they also find consistent results across different measures. In particular, board ownership and debt ratio have an effect on reducing agency costs. However, the variable of CEO tenure, nomination committee and majority of the committee being non-executive directors show increased agency costs that raises questions regarding the adoption of recommended governance mechanisms in UK-listed firms.

Fleming et al. (2005) attempt to identify the relationship between agency costs and ownership structure in non-listed Australian firms, producing similar results to those found in Ang et al. (2000). Henry (2010) also examines agency costs, corporate governance and ownership structure relationship in listed Australian companies for four different proxies of agency costs (those being total revenue to total assets ratio, sum of cash and marketable securities to total assets ratio, free cash flows to total assets ratio and Tobin's $Q$ agency dummy). The evidence suggests a non-linear relationship between board of director, external ownership, and the level of agency costs; a significant leading role of institutional ownership in reducing agency costs; a mitigating role in board independence and remuneration; a mixed role in CEO-chair duality; and limited effectiveness upon financial policy variables. Henry (2010) also argues that superior internal governance lowers the extent of agency costs, while internal governance and external shareholding influences largely substitute agency-mitigating mechanisms. Wellalage and Locke (2011) investigate the linkage between agency costs, ownership structure and corporate governance in unlisted small businesses in New Zealand. Their results indicate that ownership concentration has the most significant governance effect, with a U-shape relationship between internal ownership and agency costs, while leverage has varying effect on agency costs depending on the proxies used. Again, using a sample of French listed firms, Moez (2018) finds a negative relationship between ownership concentration and agency costs, as measured by expense ratio. Almihbash (2021) also reports a negative relationship of ownership concentration with different proxies of agency costs measures. In a related study, Chinelo and Iyiegbuniwe (2018) and Khan et al. (2020) reveal that a decrease in agency costs is followed by an increase in the level of ownership concentration.

Noravesh et al. (2009) examine the impacts of governance mechanisms on agency costs (in this case, interaction of growth prospects and free cash flows) among firms listed on the Tehran Stock Exchange, Iran. They report consistent findings of agency costs mitigating effects of institutional ownership and percentage of non-executive directors, but not for debt ratio. Furthermore, Ibrahim and Samad (2011) test agency costs (total sales to total assets ratio and total operating expense to total sales) and corporate governance relationship in Malaysian listed family and non-family firms. Their evidence suggests a significant effect of board size on both types of firms, while independent directors are effective in non-family firms only and CEO-chair duality mitigates agency costs in family firms rather than non-family firms. Recently, Nguyen et al. (2020) also examine the effect of board size on the agency costs in listed firms in Vietnam and find a negative relationship between board size and agency costs as measured by asset turnover ratio. In a cross-country study, Garanina and Kaikova (2016) also find that larger board size is related to higher agency costs.

Again, Rashid (2015) examines the influence of board independence on firm agency cost (expense ratio, asset utilization ratio and Q-free cash flows interaction) among listed firms in Bangladesh. The study finds that board independence can reduce agency cost 
only for asset utilization ratio and thus concludes that board independence and other board attributes do not reduce all facets of agency costs of a firm. He argues that outside directors' inability to monitor may be captured by the unique institutional setting of insider ownership and high representation on the board. A similar negative result is also found by Nguyen et al. (2020) in Vietnam for asset utilization ratio. Further, Vijayakumaran (2019) find that managerial ownership and debt financing work as effective governance mechanisms in mitigating agency costs (asset utilization ratio and expense ratio) in Chinese listed firms, i.e., higher managerial ownership and debt can reduce the agency costs of the firms.

Finally, with a different focus, Chen et al. (2011) predict a significant association between agency problems and cost asymmetry, and that corporate governance mitigates the positive association between agency problems and cost asymmetry. They find evidence that selling, general and administrative (SG\&A) cost asymmetry is positively related to the manager's empire building agency problem as measured by free cash flow, CEO-horizon, CEO-tenure and compensation structure. Their evidence suggests that corporate governance mechanisms play an important role in mitigating the effect of agency problems on the manager's cost adjustment decisions, as the positive association between agency problems and SG\&A cost asymmetry is more pronounced under a weak corporate governance environment.

\section{Hypotheses}

The above studies suggest that corporate governance mechanisms play an important role in mitigating the effect of the agency problem where different proxies are used as direct measurement of agency costs. The current study, by contrast, is unique in examining whether audit committee characteristics, alternative ownership concentration and other board attributes can reduce the agency costs of NZ listed firms.

Audit committees are independent committees assigned to overseeing a company's financial reporting process, protecting the interest of the firm and its value. An audit committee that is well structured, active and functional can prevent manipulation of accounting numbers undertaken by management in the interest of owners (Xie et al. 2003). Mangena and Pike (2005) document that audit committee characteristics have a positive impact in improving the disclosure process and monitoring effectiveness of the firm. In recent years, audit committee independence has been seen as one of the vital attributes of an effective corporate governance system. A more independent audit committee would be able to provide more objective monitoring of the company's internal control system. Given the existence of information asymmetries and the potential for conflict of interest between managers and shareholders, an independent audit committee offers vital governance in ensuring the integrity of financial statements, in addition to that provided by external auditors. A more independent audit committee is linked to better monitoring (Abbott et al. 2004). Each independent director in the audit committee will be motivated to provide better monitoring in order to preserve and develop their reputation (Abbott et al. 2004). Beasley et al. (2000) and Persons (2005) find that audit committee independence is negatively related to the likelihood of committing financial reporting fraud on the part of the management to deceive shareholders. A more independent audit committee appears to be more effective in performing its oversight role in reducing agency costs.

Again, it is also argued that a larger audit committee provides better governance than a smaller one, by ensuring the reliability of financial statements. A larger audit committee has more resources and expertise to oversee the financial reporting and internal control systems (Anderson et al. 2004), and thus would be more effective in uncovering fraud, manipulation and earnings management in the financial reporting process. This in turn leads to the following hypotheses:

Hypothesis 1a (H1a). Audit committee independence is negatively associated with agency costs.

Hypothesis $\mathbf{1 b} \mathbf{( H 1 b ) . ~ A u d i t ~ c o m m i t t e e ~ s i z e ~ i s ~ n e g a t i v e l y ~ a s s o c i a t e d ~ w i t h ~ a g e n c y ~ c o s t s . ~}$ 
Ownership remains at the root of agency conflict between controlling and noncontrolling parties (i.e., between managers and owners, between directors and shareholders, and between major and minor shareholders) for misalignment of their interests and the presence of information asymmetry. Farooque et al. (2007) document that the alignment of controlling and minority shareholders may not be completely achieved. Opportunistic behaviour by controlling parties could be minimized by aligning their workload and motivation and shareholders' interest maximization (Jensen 1993). According to Burkart et al. (2003), ownership structure is an important factor for alleviating the agency problems. Outside ownership concentration of large shareholders provides incentives to effectively monitor firm behaviour to maximise the value of shareholdings (Shleifer and Vishny 1986, 1997; Farooque et al. 2010). Such incentive-monitoring aspects tend to reduce the extent of agency costs. Weir et al. (2002) provide evidence of monitoring incentives by block holders for the firms to perform better. Both Florackis (2008) and Allam (2018) reports that ownership concentration has a strong effect in reducing agency costs.

Again, it is argued in the literature that agency conflict between managers and shareholders could be reduced through managerial ownership. Managers owning a larger percentage of shares have more incentive to align their interest with shareholders. Rashid (2016) finds that managerial ownership reduces firm agency cost, which is in line with the prediction of agency theory that higher insider ownership could reduce agency costs and improve performance (Crutchley and Hansen 1989). O'Callaghan (2015) contends that there is limited evidence to support the notion that managerial ownership has a positive influence on agency costs. Hence, the following hypotheses are expected:

Hypothesis 2a (H2a). Board ownership is negatively associated with agency costs.

Hypothesis $\mathbf{2 b} \mathbf{\mathbf { b }} \mathbf{\mathbf { 2 }} \mathbf{b})$. Top-20 shareholders' ownership is negatively associated with agency costs.

\section{Methodology and Data}

\subsection{Data and Sample}

This study uses secondary data from the governance structure of NZ listed companies, including ownership and financial indicators for the period 2012 to 2018. The data were collected from company annual reports and DataStream and Osiris databases. Corporate governance variables were gathered manually from company annual reports. The population of more than 250 companies listed in the NZ Stock Exchange (NZX) in a range of industries excluding financial firms forms an unbalanced panel. Based on the availability of annual reports and required data, a total of 466 observations were made with the number of companies ranging from 46 to 82 over the seven years period. These firms are affiliated in six major industry sectors, along with one miscellaneous example. To be selected as a sample, the company must have been active during the sample period; however, it is not necessary for a company to be included across the entire seven-year period. Table 1 highlights both year-wise and industry-wise percentage distribution of the sample size. Although year-wise distribution seems equitable over the period examined in particular the later years, industry concentration is evident with highest dominance in the service sector $(36.5 \%)$ followed by miscellaneous $(18.9 \%)$ and primary $(13.5 \%)$.

Table 1. Distribution of sample size.

\begin{tabular}{cccccc}
\hline Year Wise & Frequency & Percentage & Industry Wise & Frequency & Percentage \\
\hline 2012 & 46 & 9.9 & Energy & 31 & 6.7 \\
2013 & 53 & 11.4 & Goods & 56 & 12 \\
2014 & 55 & 11.8 & Investment & 44 & 9.4 \\
2015 & 72 & 15.5 & Primary & 63 & 13.5 \\
2016 & 78 & 16.7 & Property & 14 & 3 \\
2017 & 80 & 17.2 & Service & 170 & 36.5 \\
2018 & 82 & 17.6 & Miscellaneous & 88 & 18.9 \\
Total & 466 & 100 & Total & 466 & 100 \\
\hline
\end{tabular}




\subsection{Measurement of Agency Costs}

This study operationalises direct measurement of agency costs as dependent variable, instead of using traditional backward-looking accounting performance measures. In the literature, different measures of agency costs are used, such as asset utilisation/turnover ratio (total sales or revenue to total assets ratio), expense ratio (total operating expense to total sales ratio, SG\&A to sales ratio), asset liquidity ratio (sum of cash and marketable securities to total assets ratio), free cash flow to assets ratio, Tobin's $Q$ as growth prospect, interaction of free cash flow and growth prospects, and number of acquisitions. These measures are either backward-looking (asset utilisation/turnover ratio, expense ratio) or forward-looking (free cash flow, Tobin's $Q$ as growth prospect) and there are potential drawbacks in the former measures (see (McKnight and Weir 2009)). Moreover, because of the asymmetric nature, expense and cost ratios are labelled as 'cost stickiness' (Chen et al. 2011).

On the other hand, forward-looking measures are regarded as more effective ones for detecting agency costs. Opler and Titman (1993) argue that firms with high growth prospects are less likely to have excess free cash flows because the available cash will be spent on positive net present value projects. Doukas et al. (2000) contend that agency costs may be considered as a function of the interaction of growth opportunities and free cash flow and firms that combine low growth prospects and high free cash flow can, therefore, be regarded as suffering from high agency costs. Because, greater retention of free cash flows within the firm envisages as being indicative of potential agency problems and the existence of agency costs. Free cash flow is a commonly used proxy for the agency problem and the resulting 'empire building' incentives (managers' personal utility from status, power, compensation, and prestige) that arises when there is a mismatch between available cash and growth prospects (Jensen 1986). Jensen (1986) proposes that agency costs are high when high free cash flows are combined with poor growth opportunities. When free cash flow is high, managers have greater opportunity for overinvesting in operations or negative net present value projects. By contrast, when free cash flow is low, managers have less opportunity for empire building and they are more likely to avoid negative career consequences. Hence, large free cash flows suggest greater managerial discretion and higher agency costs.

Following prior studies (McKnight and Weir 2009; Henry 2010; Chen et al. 2011), this study uses two measures of agency costs focusing on firm's growth opportunities: (1) growth prospect (Tobin's Q Dummy) and (2) interaction of free cash flows and Tobin's $\mathrm{Q}\left(\mathrm{FCF}^{*} \mathrm{QDUMMY}\right)$.

The first agency cost is the growth prospect or indicator of forward-looking firm performance (Tobin's Q), following Henry (2010). Firms with Tobin's Q ratios greater than 1.00 are perceived as well-managed firms that are creating value for shareholders, whereas firms with Tobin's $Q$ ratios less than unity are destroying shareholder value that is associated with agency costs. It is calculated where $Q$ ratios higher than 1.00 identify as high growth firms and lower than 1.00 identify low growth firms. This indicator variable is assigned a value of one if the firm's Tobin's $Q$ ratio is greater than 1.00, and is given a value of zero if the Tobin's Q ratio is less than or equal to 1.00. The lower growth firms have poor performing managers, with wastage of resources giving rise to agency costs.

The second agency cost proxy used is the 'interactions' of free cash flow and growth prospects (FCF*QDUMMY), following McKnight and Weir (2009) and Noravesh et al. (2009). Firms with low or poor growth prospects cannot utilise their free cash flows and are expected to have greater managerial discretion and higher agency costs (Jensen 1986). In other words, agency costs are more persistent in firms with a high level of liquid assets and free cash flow. To capture this cost, firstly, $Q$ is calculated for each firm as well as the median value for the total sample firms, following Noravesh et al. (2009). The sample median value $(0.885)$ is then subtracted from the individual $Q$ ratio of each firm and a $Q$ indicative variable is constructed with a value of one if firms' $Q$ ratios are less than sample means (1.345), and a value of zero if above the mean. Secondly, Following Doukas et al. 
(2000) and McKnight and Weir (2009) free cash flows are measured as operating income before depreciation minus taxes plus interest and dividends paid and then scaled by total assets. Finally, an interaction variable is created through multiplication of free cash flow and $Q$ indicative variables, which thus becomes a continuous variable showing free cash flow values for low growth firms and zero values for high growth firms. The low growth firms or high value of the interactive variable is indicative of high agency costs (Florackis 2008). Firms that combine low growth opportunities and high free cash flow are more likely to suffer from high agency costs.

\subsection{Regression Model}

To test the hypotheses of the study, the following regression model is developed:

AGENCY COSTS $_{i t}=\alpha+\beta_{1}$ AC IND $_{\text {it }}+\beta_{2}$ AC SIZE $_{\text {it }}+\beta_{3}$ BSHARE $_{\text {it }}$ or TOP-20 SHARE SH + $\beta_{4}$ BSIZE $_{i t}+\beta_{5}$ BIND $_{i t}+\beta_{6}$ DUALITY $_{i t}+\beta_{7}$ DEBT RATIO $_{i t}+\beta_{8}$ ROA $_{i t}+\beta_{9}$ INV-REC RATIO $_{i t}+$ $\beta_{10}$ LNSALE $_{i t}+$ IND-DUM + YEAR-DUM $+\varepsilon_{\text {it }}$

Table 2 outlines the measurement technique of the dependent and independent and control variables in the regression model. In the current study, the main variable of interest is audit committee independence and size, followed by board shareholdings and top-20 shareholdings. Top-20 ownership concentration exceeds more than $50 \%$ ownership of the firm, while board ownership remains below 50\% level, indicating high and low levels of concentration, respectively. A number of control variables consistent with prior literature have been used and industry and year dummy variables are incorporated in the regression model to cope with unobserved heterogeneity mentioned earlier.

Table 2. Variable description.

\begin{tabular}{|c|c|}
\hline Variable & Description \\
\hline \multicolumn{2}{|l|}{ Dependent measures: } \\
\hline TOBIN'S Q DUMMY & $\begin{array}{l}\text { Q is the market capitalisation plus total debt divided by total assets. Q dummy is denoted as value } 1 \text { if a firm's Q ratio is } \\
\text { higher than } 1.00 \text { indicating a well-managed company and } 0 \text { when the ratio is equal to or lower than } 1.00 \text {. (Henry 2010) }\end{array}$ \\
\hline FCF*QDUMMY & $\begin{array}{l}\text { Free cash flow (FCF) is the operating income before depreciation minus taxes plus interest and dividends paid scaled by } \\
\text { total assets. Q dummy is constructed with a value of } 1 \text { if a firm's Q ratio is less than sample means (1.345) indicating a } \\
\text { poorly managed company, and } 0 \text { if above the mean. Interaction variable is created through multiplication of FCF and Q } \\
\text { dummy variables. (Doukas et al. 2000; McKnight and Weir 2009) }\end{array}$ \\
\hline \multicolumn{2}{|l|}{ Independent measures: } \\
\hline AC IND & Percentage of independent directors to the total number of directors on the audit committee. \\
\hline AC SIZE & Total number of directors on the audit committee. \\
\hline BSHARE & Board shareholding as a percentage of total outstanding shares, indicating low concentration. (Ang et al. 2000) \\
\hline TOP-20 SHARE & Top-20 shareholding as a percentage of total outstanding shares, indicating high concentration. (Hossain et al. 2001) \\
\hline \multicolumn{2}{|l|}{ Control variables: } \\
\hline BSIZE & Total number of directors on the board. (Rashid 2015) \\
\hline BIND & Percentage of independent directors to the total number of directors on the board. (Rashid 2015 ) \\
\hline DUALITY & Dummy variable denoted as value 1 if the chairperson is in the role of CEO and 0 otherwise. (Rashid 2015) \\
\hline DEBT RATIO & Total debt to total assets. \\
\hline $\mathrm{ROA}$ & Net profit to total assets. \\
\hline INV-REC RATIO & Total inventory to accounts receivable. \\
\hline LNSALE & Firm size as log sales. \\
\hline IND-DUM & 7 industry dummies. \\
\hline YEAR-DUM & 7 year dummies. \\
\hline
\end{tabular}

Depending on the nature of the dependent variables, both Logistic and Ordinary Least Square (OLS) regressions are employed, respectively, for Tobin's Q dummy and FCF*QDUMMY. The literature records panel data analysis as an efficient statistical approach that consists of cross-sectional and time series data, with a structure that takes into 
account unobservable and consistent heterogeneity. Following the literature, this study does not consider the direction of any endogeneity/causality between directly measured agency costs and audit or ownership variables. In fact, endogeneity/causality effect is more prevalent in ownership/governance and performance models that are determined by firm characteristics. Instead, following Hausman test, it adopts fixed effects as used in Himmelberg et al. (1999) to adjust for unobservable heterogeneity across the sample firms for consistent estimates. Since unobserved firm-specific effects are time variant and differ between firms, fixed effect estimates provide a robustness test of pooled estimates of the OLS regression model. Fixed effects also handle omitted variable bias problems and provide robust estimates. In this way, both pooled sample effects (the impact of governance variables on agency costs) and fixed effects (the impact of time variant and industry sector on the relationship between governance variables and agency costs) are tested in a multivariate regression model (logistic and OLS) that confirms that coefficient-estimates are reliable and unbiased.

\section{Empirical Results}

Table 3 presents the descriptive statistics for the sample firms over the seven years period. It finds that the mean and median Tobin's Q ratio for sample firms are 1.345 and 0.885, respectively, with approximately $40 \%$ of firm-year observations recording Tobin's $\mathrm{Q}$ ratios higher than 1.00. These values are comparable to the mean (median) Tobin's $Q$ ratios of 2.192 (1.400) in Doukas et al. (2005) for the US listed firms and 1.252 (1.112) in Henry (2010) for Australian listed firms. Similarly, the mean and median of free cash flow ratio are 0.024 and 0.071 , respectively, compared to 0.042 and 0.053 in Henry (2010) for Australian listed firms. Given different time and sample differences, these ratios indicate that NZ companies experience greater agency costs than the US companies and lower agency costs than Australian companies. In regard to the ownership and governance attributes in Table 3, the average board ownership is 23\%, while Top-20 shareholders ownership is $66 \%$, consistent with prior studies on NZ showing a high concentration of outside block ownership and mostly involving financial institutions. Average board size is relatively small with six members, of which $25 \%$ are independent directors and $28 \%$ firms have CEO-chairman duality. Again, average audit committee size is three members with $30 \%$ representation from independent directors. Finally, debt ratio is shown as one-quarter of total assets, thus indicating low leverage ratio.

Table 3. Summary statistics.

\begin{tabular}{cccccc}
\hline Variables & Mean & Median & $\begin{array}{c}\text { Std. } \\
\text { Deviation }\end{array}$ & Minimum & Maximum \\
\hline TOBIN'S Q & 0.40 & 0.00 & 0.490 & 0 & 1 \\
DUMMY & & 0.060 & 0.123 & -0.84 & 0.42 \\
FCF*QDUMMY & 0.065 & 0.00 & 0.391 & 0.00 & 1.00 \\
AC IND & 0.296 & 3.0 & 1.813 & 0 & 8 \\
AC SIZE & 2.76 & 0.119 & 0.269 & 0.00 & 1.59 \\
BSHARE & 0.229 & 0.715 & 0.211 & 0.00 & 0.987 \\
TOP20 & 0.663 & 6.0 & 1.651 & 3 & 12 \\
SHARE & 6.05 & 0.000 & 0.297 & 0.00 & 1.00 \\
BSIZE & 0.252 & 0.000 & 0.448 & 0 & 1 \\
BIND & 0.28 & 0.215 & 0.261 & 0.00 & 3.78 \\
DUALITY & 0.243 & 0.010 & 30.97 & -290.99 & 45.16 \\
DEBT RATIO & 0.046 & 0.262 & 0.227 & 0.00 & 0.85 \\
ROA & 0.305 & 11.57 & 2.274 & 2.94 & 15.89 \\
INV-REC & 11.20 & & &
\end{tabular}


Table 4 reports the Pearson correlation matrix of the relationship between all dependent and independent variables within the analysis, except for the year and industry dummies. The majority of the correlations are statistically significant, but small in magnitude; however, there is no sign of multicollinearity problem. Again, a multicollinearity diagnostic test is conducted for all independent variables in the model. The tolerance defined as the Variance Inflation Factors (VIF) is less than 10 for all variables used in two different dependent variables for agency costs, suggesting no serious multicollinearity concern. ${ }^{3}$ As such, there is no potential problem of serious multicollinearity contaminating the multivariate regression model.

Table 4. Pearson correlation matrix for variables.

\begin{tabular}{|c|c|c|c|c|c|c|c|c|c|c|c|c|c|}
\hline Variables & (1) & (2) & (3) & (4) & (5) & (6) & (7) & (8) & (9) & (10) & (11) & (12) & (13) \\
\hline (1) TOBIN'S Q DUMMY & 1 & $0.104 * *$ & $0.088^{*}$ & 0.031 & $-0.154 * * *$ & -0.021 & 0.055 & 0.113 ** & -0.023 & 0.007 & $-0.093 *$ & 0.003 & $-0.153^{* * *}$ \\
\hline (2)QDUMMY*FCF & & 1 & -0.058 & $0.076^{*}$ & $0.183^{* * *}$ & -0.036 & $0.200 * * *$ & 0.093 ** & -0.070 & 0.055 & $0.373^{* * *}$ & 0.071 & $0.371^{* * *}$ \\
\hline (3) BSHARE & & & 1 & $0.161^{* * *}$ & $-0.328^{* * *}$ & $-0.198^{* * *}$ & $-0.273^{* * *}$ & 0.031 & $0.143^{* * *}$ & -0.009 & -0.051 & $0.258^{* * *}$ & $-0.133^{* * *}$ \\
\hline (4) TOP20 SHARE & & & & 1 & $-0.209 * * *$ & 0.003 & -0.019 & $-0113^{* *}$ & -0.042 & $-0.083 *$ & 0.033 & $-0.191 * * *$ & 0.063 \\
\hline (5) BSIZE & & & & & 1 & 0.065 & $0.495 * * *$ & 0.089 * & $-0.315^{* * *}$ & 0.066 & $0.233^{* * *}$ & -0.046 & $0.509 * * *$ \\
\hline (6) BIND & & & & & & 1 & $0.221 * * *$ & $-0.277^{* * *}$ & -0.128 ** & 0.032 & 0.121 ** & $-0.102 * *$ & $0.183^{* * *}$ \\
\hline (7) AC SIZE & & & & & & & 1 & $0.274^{* * *}$ & $-0.211^{* * *}$ & 0.072 & $0.178^{* * *}$ & $-0.234^{* * *}$ & $0.347^{* * *}$ \\
\hline (8) AC IND & & & & & & & & 1 & $-0.100^{* *}$ & $0.104^{* *}$ & $0.152^{* * *}$ & $0.190^{* * *}$ & $0.260 * * *$ \\
\hline (9) DUALITY & & & & & & & & & 1 & 0.015 & $-0.184^{* * *}$ & $0.083 *$ & $-0.307^{* * *}$ \\
\hline (10) DEBT RATIO & & & & & & & & & & 1 & 0.020 & -0.033 & $0.283^{* * *}$ \\
\hline (11) ROA & & & & & & & & & & & 1 & 0.060 & $0.515 * * *$ \\
\hline (12) INV-REC RATIO & & & & & & & & & & & & 1 & $0.156^{* * *}$ \\
\hline (13) LNSALE & & & & & & & & & & & & & 1 \\
\hline
\end{tabular}

Both logistic and OLS regression results are reported in Tables 5 and 6 for each of the proxies of agency costs used as a dependent variable. A total of four models are estimated to show regression results. As mentioned, two alternative measures of ownership variables (i.e., board ownership and Top-20 shareholders ownership) are used in this study separately along with both year dummy and industry dummy variables. While the variables of interest are audit independence and size, Models 1 and 2 show board ownership with and without fixed industry and year dummy variables, respectively, and Models 3 and 4 Top20 shareholders ownership with and without fixed industry and year dummy variables, respectively.

\subsection{Agency Costs in Terms of Tobin's Q Dummy as Growth Prospect/Firm Performance}

Table 5 above presents logistic regression results for the Tobin's $Q$ dummy as the measure of agency costs. The variable of interest audit committee independence (AC IND) documents a significant positive relationship with Tobin's $Q$ dummy, as expected, in all models with either board or Top-20 shareholdings. This finding implies that independent audit committee directors contribute to the growth prospect of firms through intense monitoring and deterring agency costs. Audit committee size also shows a positive effect on Tobin's $Q$ dummy, indicating bigger size is good for performing its overseeing task with independent directors. Both audit committee independence and size demonstrate their effectiveness in reducing agency costs, or, in other words, fostering performance and growth. On the contrary, board and Top-20 shareholdings are found to have positive effects, but are mostly insignificant except fixed-effect model (model 2) for board shareholdings showing weak convergence of interest effect. Similarly, contrary to expectation, both board independence and size appear to have negative effects in, respectively, fixed-effect (models 2 and 4) and non-fixed-effect (models 1 and 3) models. However, duality is showing negative significant impact though at lower significant level, which pushes agency costs to increase. 
Table 5. Logistic regression results (agency costs: TOBIN'S Q DUMMY).

\begin{tabular}{|c|c|c|c|c|c|}
\hline \multirow{2}{*}{ VARIABLES } & \multirow{2}{*}{ Expected Sign } & MODEL 1 & MODEL 2 & MODEL 3 & MODEL 4 \\
\hline & & Coef. & Coef. & Coef. & Coef. \\
\hline INTERCEPT & & $\begin{array}{l}1.901^{* *} \\
(5.838)\end{array}$ & $\begin{array}{c}-2.102 * \\
(2.685)\end{array}$ & $\begin{array}{l}1.484 * \\
(2.991)\end{array}$ & $\begin{array}{l}-1.539 \\
(1.373)\end{array}$ \\
\hline AC IND & + & $\begin{array}{l}0.574 \text { * } \\
(3.080)\end{array}$ & $\begin{array}{l}1.677^{* * * *} \\
(15.777)\end{array}$ & $\begin{array}{l}0.663 * * \\
(3.975)\end{array}$ & $\begin{array}{l}1.626^{* * *} \\
(15.708)\end{array}$ \\
\hline AC SIZE & $+1-$ & $\begin{array}{l}0.311^{* * *} \\
(13.447)\end{array}$ & $\begin{array}{c}0.157 \\
(2.534) \\
\end{array}$ & $\begin{array}{l}0.304^{* * *} \\
(13.789)\end{array}$ & $\begin{array}{l}0.168 * \\
(3.293)\end{array}$ \\
\hline BSHARE & + & $\begin{array}{c}0.266 \\
(0.360)\end{array}$ & $\begin{array}{l}1.032 * \\
(3.413)\end{array}$ & & \\
\hline TOP20 SHARE & + & & & $\begin{array}{c}0.723 \\
(1.387) \\
\end{array}$ & $\begin{array}{c}0.683 \\
(0.997)\end{array}$ \\
\hline BSIZE & $+/-$ & $\begin{array}{c}-0.242^{* * *} \\
(-6.366)\end{array}$ & $\begin{array}{l}-0.139 \\
(1.559)\end{array}$ & $\begin{array}{c}-0.217^{* *} \\
(5.211)\end{array}$ & $\begin{array}{l}-0.177 \\
(2.553)\end{array}$ \\
\hline BIND & + & $\begin{array}{c}0.208 \\
(0.249)\end{array}$ & $\begin{array}{c}-1.147^{* * *} \\
(4.580)\end{array}$ & $\begin{array}{c}0.155 \\
(0.144)\end{array}$ & $\begin{array}{c}-1.144^{* *} \\
(4.893)\end{array}$ \\
\hline DUALITY & - & $\begin{array}{c}-0.572^{* *} \\
(4.126)\end{array}$ & $\begin{array}{c}-0.623 * \\
(3.007)\end{array}$ & $\begin{array}{c}-0.574^{* *} \\
(4.633)\end{array}$ & $\begin{array}{c}-0.578 * \\
(3.331)\end{array}$ \\
\hline DEBT RATIO & + & $\begin{array}{c}0.535 \\
(1.390)\end{array}$ & $\begin{array}{c}0.473 \\
(0.682)\end{array}$ & $\begin{array}{c}0.528 \\
(1.311)\end{array}$ & $\begin{array}{c}0.230 \\
(0.213)\end{array}$ \\
\hline ROA & + & $\begin{array}{c}0.001 \\
(0.072)\end{array}$ & $\begin{array}{l}-0.007 \\
(1.483)\end{array}$ & $\begin{array}{c}0.000 \\
(0.000)\end{array}$ & $\begin{array}{l}-0.007 \\
(1.583)\end{array}$ \\
\hline INV-REC RATIO & + & $\begin{array}{l}1.216^{* *} \\
(4.771)\end{array}$ & $\begin{array}{l}-0.081 \\
(0.011)\end{array}$ & $\begin{array}{l}1.241 * * \\
(5.395)\end{array}$ & $\begin{array}{c}0.137 \\
(0.040) \\
\end{array}$ \\
\hline LNSALES & + & $\begin{array}{c}-0.212^{* * *} \\
(8.310)\end{array}$ & $\begin{array}{c}0.020 \\
(0.048) \\
\end{array}$ & $\begin{array}{c}-0.229^{* * *} \\
(9.269)\end{array}$ & $\begin{array}{c}-0.038 \\
(0.182)\end{array}$ \\
\hline YEAR-DUM & & & YES & & YES \\
\hline IND-DUM & & & YES & & YES \\
\hline OBS & & 392 & 392 & 421 & 421 \\
\hline Chi-Square for Model & & $40.398^{* * *}$ & $130.579^{* * *}$ & $44.806^{* * *}$ & $120.290^{* * *}$ \\
\hline Pseudo-R ${ }^{2}$ & & 0.132 & 0.383 & 0.137 & 0.337 \\
\hline
\end{tabular}

$* * *, * *$ Significant at the $1 \%, 5 \%$, and $10 \%$ levels, respectively. These models provide Wald Chi-square, which is in parentheses.

\subsection{Agency Costs in Terms of Interaction of Free Cash Flows and Growth Prospects}

Table 6 reports OLS regression results for the interaction of free cash flows and growth prospects as a measure of agency costs. As expected, audit committee independence (AC IND) reveals deterring effect on agency costs. Ratios of independent directors on the board also provide significant and consistent deterring effect on agency costs. Board size is significant with expected negative sign in all models, indicating higher board size leads to reduce agency costs. However, contrary to expectation, audit committee size appears to have a positive relationship, implying that small size is more effective in reducing agency costs than large size. Similarly, Top-20 shareholding has no significant influence on agency costs, while board shareholding still shows an incentive alignment effect of reducing agency cost, albeit at $10 \%$ significance levels (Models 2). 
Table 6. OLS regression results (Agency Costs: FCF * QDUMMY).

\begin{tabular}{|c|c|c|c|c|c|}
\hline \multirow{2}{*}{ VARIABLES } & \multirow{2}{*}{ Expected Sign } & MODEL 1 & MODEL 2 & MODEL 3 & MODEL 4 \\
\hline & & Coef. & Coef. & Coef. & Coef. \\
\hline INTERCEPT & & $\begin{array}{c}-0.047 \\
(-1.191)\end{array}$ & $\begin{array}{c}-0.062 \\
(-1.151)\end{array}$ & $\begin{array}{l}-0.073 * \\
(-1.721)\end{array}$ & $\begin{array}{c}-0.080 \\
(-1.458)\end{array}$ \\
\hline AC IND & - & $\begin{array}{l}-0.052 * * * \\
(-3.016)\end{array}$ & $\begin{array}{l}-0.042^{* *} \\
(-2.413)\end{array}$ & $\begin{array}{c}-0.050^{* * *} \\
(-2.962)\end{array}$ & $\begin{array}{l}-0.042^{* *} \\
(-2.436)\end{array}$ \\
\hline AC SIZE & $+1-$ & $\begin{array}{c}0.016^{* * *} \\
(3.806)\end{array}$ & $\begin{array}{c}0.015^{* * *} \\
(3.545)\end{array}$ & $\begin{array}{c}0.016^{* * *} \\
(3.963)\end{array}$ & $\begin{array}{c}0.016^{* * *} \\
(3.777)\end{array}$ \\
\hline BSHARE & - & $\begin{array}{c}-0.034 \\
(-1.491)\end{array}$ & $\begin{array}{l}-0.062 * \\
(-1.720)\end{array}$ & & \\
\hline TOP-20 SHARE & - & & & $\begin{array}{c}0.007 \\
(0.231)\end{array}$ & $\begin{array}{c}0.007 \\
(0.220)\end{array}$ \\
\hline BSIZE & $+1-$ & $\begin{array}{l}-0.010 * * \\
(-2.063)\end{array}$ & $\begin{array}{l}-0.008 * \\
(-1.717)\end{array}$ & $\begin{array}{l}-0.008 * \\
(-1.777)\end{array}$ & $\begin{array}{l}-0.008 * \\
(-1.659)\end{array}$ \\
\hline BIND & - & $\begin{array}{c}-0.088^{* * *} \\
(-4.082)\end{array}$ & $\begin{array}{l}-0.058^{* *} \\
(-2.428)\end{array}$ & $\begin{array}{c}-0.081^{* * *} \\
(-3.946)\end{array}$ & $\begin{array}{l}-0.053^{* *} \\
(-2.285)\end{array}$ \\
\hline DUALITY & + & $\begin{array}{c}0.007 \\
(0.510)\end{array}$ & $\begin{array}{c}0.020 \\
(1.315)\end{array}$ & $\begin{array}{c}0.006 \\
(0.440)\end{array}$ & $\begin{array}{c}0.016 \\
(1.134)\end{array}$ \\
\hline DEBT RATIO & - & $\begin{array}{c}-0.002 \\
(-0.080)\end{array}$ & $\begin{array}{c}-0.027 \\
(-1.199)\end{array}$ & $\begin{array}{c}-0.006 \\
(-0.278)\end{array}$ & $\begin{array}{c}-0.025 \\
(-1.127)\end{array}$ \\
\hline ROA & - & $\begin{array}{c}0.001^{* * *} \\
(5.913)\end{array}$ & $\begin{array}{c}0.001^{* * *} \\
(5.167)\end{array}$ & $\begin{array}{c}0.001^{* * *} \\
(6.026)\end{array}$ & $\begin{array}{c}0.001^{* * *} \\
(5.403)\end{array}$ \\
\hline INV-REC RATIO & - & $\begin{array}{c}0.070 * * * \\
(2.459)\end{array}$ & $\begin{array}{c}0.102 * * * \\
(3.175)\end{array}$ & $\begin{array}{l}0.048 * \\
(1.789) \\
\end{array}$ & $\begin{array}{l}0.069 * * \\
(2.284)\end{array}$ \\
\hline LNSALES & - & $\begin{array}{c}0.014^{* * *} \\
(3.688)\end{array}$ & $\begin{array}{l}0.010 * * \\
(2.390)\end{array}$ & $\begin{array}{c}0.014^{* * *} \\
(3.867)\end{array}$ & $\begin{array}{c}0.011^{* * *} \\
(2.859)\end{array}$ \\
\hline YEAR-DUM & & & YES & & YES \\
\hline IND-DUM & & & YES & & YES \\
\hline OBS & & 395 & 395 & 424 & 424 \\
\hline F-Stat & & $12.671^{* * *}$ & $8.012^{* * *}$ & $13.351^{* * *}$ & $7.969^{* * *}$ \\
\hline ADJ-R ${ }^{2}$ & & 0.228 & 0.281 & 0.226 & 0.266 \\
\hline
\end{tabular}

$* * *, * * *$ Significant at the $1 \%, 5 \%$, and $10 \%$ levels, respectively. These models provide t-statistics which are in parentheses.

As for robustness check, the key finding of this study, i.e., significant impact of audit committee independence (AC IND) in deterring agency costs remains consistent and robust across the proxies and models in Tables 5 and 6 with either board or Top-20 shareholdings. No unobservable heterogeneity is found when industry and year dummies are employed. However, in Table 5 with Tobin's Q dummy, the effect of board independence on agency cost after controlling for industries and time has changed from positive insignificant to negative significant which is beyond expectation. This implies that board independence and other attributes of board such as size to some extent vary across industries and time. Despite this variation, overall results confirm robustness of the main findings. Furthermore, alternative measures of audit committee independence and size, board independence and size, and board and Top-20 shareholdings are considered to replicate the regression analysis. The results reveal no material variations of the base-line findings reported before. ${ }^{4}$

\section{Discussion and Conclusions}

From a risk management standpoint, this study explores longstanding debates concerning alignment of interest, efficient monitoring and entrenchment arguments in the 
NZ setting with its distinctive nature of high concentration of ownership. The empirical results above reveal some important findings, in particular on the relationship between audit committee independence and direct measures of agency costs proxies in NZ listed companies. Results document that audit committee independence has strong deterrent effect on agency costs, which indicates efficient monitoring is in place to mitigate agency costs. Therefore, hypothesis $\mathrm{H}_{1 \mathrm{a}}$ is supported. However, audit committee size does not appear as strong as audit committee independence in alleviating agency costs. It shows significant relation in the opposite direction with the two proxies of agency costs (i.e., TOBIN'S Q DUMMY and FCF * QDUMMY), suggesting that either a larger or smaller audit committee size helps firms to reduce agency costs, respectively. As such, hypothesis $\mathrm{H}_{1 \mathrm{~b}}$ is marginally supported. This is because audit committees are usually dominated by independent directors, irrespective of their size. As such, it is expected that larger audit committees are represented by more independent directors. Therefore, since independent audit committee directors demonstrate negative association with agency costs, the likelihood that larger audit committees will increase agency costs is to be mitigated with the presence of independent directors having a restraining effect on agency costs. Notwithstanding of this explanation, both audit committee independence and size are not used in the prior studies on direct measurement of agency costs. Therefore, these new findings warrant the due attention of stakeholders and regulators.

The study also documents how board ownership plays a positive role in restraining agency costs, providing support for aligned interest to improve firm performance and value, in particular in fixed-effect models with both proxies of agency costs. Therefore, hypothesis $\mathrm{H}_{2 \mathrm{a}}$ is partially supported. This result is consistent with the findings of (Ang et al. 2000; Singh and Davidson III 2003; Fleming et al. 2005; Florackis 2008; McKnight and Weir 2009; Vijayakumaran 2019), but contrary to Rashid (2015). On the contrary, despite the non-existence of apparent entrenchment of outside block-holders, outside ownership concentration (Top-20 shareholding) plays no role in reducing agency costs. Top20 shareholding remains insignificant across the models, showing that outsider ownership, in particular institutional presence, does not result in superior monitoring service in NZ due to conflict between diverse interest groups and free-rider effects. Therefore, hypothesis $\mathrm{H}_{2 b}$ is not supported. Although such finding is contrary to that of Moez (2018), but not uncommon in the literature. For example, Singh and Davidson III (2003) indicate a limited effect of outside block ownership, Rashid (2015) reports no significant effect and Henry (2010) shows a non-linear relationship between external ownership and agency costs.

In respect to board related variables, both board size and independence show inconclusive findings, though they appeared as an important set of devices in mitigating agency costs. While a reasonably smaller board size can effectively encourage pursuit of aligned interest to reduce agency costs, in NZ the average board size (6 members) is much lower than internationally accepted level (8-10 members). Thus, a moderate increase in board size will still be efficient to curb agency costs. Similar findings are found in (Singh and Davidson III 2003; Ibrahim and Samad 2011; Garanina and Kaikova 2016; Nguyen et al. 2020), and are suggestive of smaller board sizes helping alleviate agency costs. Again, independent director's ratio on the board is also small (25\%), which suggests there is a need to increase the ratio of independent members on the boards. While Henry (2010), Noravesh et al. (2009) and Nguyen et al. (2020) report a mitigating effect of board independence, Singh and Davidson III (2003) find that independent board members produced no such effect, and Ibrahim and Samad (2011) show effective role in non-family firms only, not family firms. The mixed findings of this study highlights that the role of board independence in either direction depends on the dominant position of insider or outsider ownership. Furthermore, CEO-chair duality is revealed as potentially aggravating agency costs. This emphasises the need for the roles of CEO and board chair to be dissociated. This result is contradictory to Ibrahim and Samad (2011) in showing its mitigating role in family firms, but consistent with Henry (2010), where a mixed role is evident. 
Thus, the findings of this study shed light on the effectiveness of audit independence and size as well as internal ownership concentration, and other board related variables in reducing agency costs and improving firm performance in NZ companies, being the smallest economy in the OECD. In terms of monitoring roles and incentive alignment in NZ listed companies having less minority investor protection, these results have important policy implications for regulators, companies, investors and other stakeholders. These findings are important as they can assist regulators and stakeholders in formulating appropriate corporate governance control mechanisms, so as to protect the interests of common shareholders and other stakeholders in corporate settings in New Zealand. The findings of this study can also be generalised in other emerging countries with poor enforcement of regulation and weaker investor protection to shape their governance mechanisms in order to constrain agency costs and enhance firm value. Corporate managers will be aware of putting appropriate mechanisms and resources in a firm setting that can incentivise all shareholders and stakeholders including them. It is, thus, expected that emerging economies can take lesson from the findings of the current study.

The outcomes of this study need to be interpreted in the light of some limitations, which open up avenues for future research. The first limitation is related to the study sample period as well as exclusion of financial firms. Future research should aim to extend the sample period and include financial firms. A comparative analysis could also be conducted between the financial and non-financial sectors. Second, the impact of the COVID-19 pandemic related risk is not covered in this study within its data period, which deserves further exploration in future studies. Third, the current study has the limitation of focusing on a single OECD country and its unique characteristics of the economy. Future research could undertake a similar type of investigation in other OECD countries from a comparative viewpoint. Fourth, this study uses only forward-looking agency cost measures focusing on firms' growth opportunities, rather than backward-looking measures. Future studies are expected to conduct comparative analysis of both types of measures. Fifth, this paper concentrates on ownership concentration, board and its sub-committee governance to find their association with direct measures of agency costs, but have not considered other firm-specific policies such as dividend policies, executive compensation, etc. Future research could include such specific policies to examine and capture the relationships in OECD countries from broader perspectives.

Funding: This research received no external funding.

Institutional Review Board Statement: Not applicable.

Informed Consent Statement: Not applicable.

Conflicts of Interest: The authors declare no conflict of interest.

\section{Notes}

1 Existing literature mainly focuses on board and ownership-related variables in dealing with direct measures of agency costs.

2 Hossain et al. (2001) report the average of the 'Top-20 shareholdings' in NZ is 73\%, while this study found the mean proportion to be $66 \%$ during the 2001-2007 period. ICANZ (2003) contends that financial institutions are the main player in the stock market, while individual investors account for less than a quarter. By contrast, Demsetz and Lehn (1985) show the same at $37.66 \%$ in the US.

3 VIF values are not reported in the paper for brevity, but are available from the author upon request.

4 For brevity, these results are not tabulated here, but are available from the author upon request.

\section{References}

Abbott, Lawrence J., Susan Parker, and Gary F. Peters. 2004. Audit committee characteristics and Restatements. Auditing: A Journal of Practice and Theory 23: 69-87. [CrossRef]

Allam, Bahaaeldin Samir. 2018. The impact of board characteristics and ownership identity on agency costs and firm performance: UK evidence. Corporate Governance 18: 1147-76. [CrossRef]

Almihbash, Muteb Ahmed. 2021. Agency Costs, Ownership Structure and Dividend Policy in Saudi Listed Firms: A Simultaneous Equations Approach. Ph.D. dissertation, University of New England, Armidale, Australia. 
Anderson, Ronald C., Sattar A. Mansi, and David M. Reeb. 2004. Board characteristics, accounting report integrity and the cost of debt. Journal of Accounting and Economics 37: 315-42. [CrossRef]

Ang, James S., Rebel A. Cole, and James Wuh Lin. 2000. Agency costs and ownership structure. Journal of Finance 55: 81-106. [CrossRef]

Beasley, Mark S., Joseph V. Carcello, Dana R. Hermanson, and Paul D. Lapides. 2000. Fraudulent financial reporting: Consideration of industry traits and corporate governance mechanisms. Accounting Horizons 14: 441-54. [CrossRef]

Berle, Adolf A., and Gardiner C. Means. 1932. The Modern Corporation and Private Property. New York: Commerce Clearing House.

Brennan, Niamh. 2006. Boards of directors and firm performance: Is there an expectation gap? Corporate Governance 14: 577-93. [CrossRef]

Burkart, Mike, Fausto Panunzi, and Andrei Shleifer. 2003. Family firms. The Journal of Finance 58: 2167-201. [CrossRef]

Chen, Clara Xiaoling, Hai Lu, and Theodore Sougiannis. 2011. The agency problem, corporate governance, and the asymmetrical behaviour of selling, general and administrative costs. Contemporary Accounting Research 19: 252-82.

Chinelo, Eboiyehi Osazemen, and Willi Iyiegbuniwe. 2018. Ownership structure, corporate governance and agency cost of manufacturing companies in Nigeria. Research Journal of Finance and Accounting 9: 16-26.

Crutchley, Claire E., and Robert S. Hansen. 1989. A test of the agency theory of managerial ownership, corporate leverage, and corporate dividends. Financial Management 18: 36-46. [CrossRef]

Demsetz, Harold, and Kenneth Lehn. 1985. The structure of corporate ownership: Causes and Consequences. The Journal of Political Economy 93: 1155-577. [CrossRef]

Doukas, John A., Chansog Kim, and Christos Pantzalis. 2000. Security analysis, agency costs and company Characteristics. Financial Analysts Journal 56: 54-63. [CrossRef]

Doukas, John A., Phillip J. McKnight, and Christos Pantzalis. 2005. Security analysis, agency costs and UK firm Characteristics. International Review of Financial Analysis 14: 493-507. [CrossRef]

Fama, Eugene F., and Michael C. Jensen. 1983. Separation of ownership and control. Journal of Law and Economics 26: 301-26. [CrossRef]

Farooque, Omar Al, Tony van Zijl, Keitha Dunstan, and Wares Karim. 2007. Corporate governance in Bangladesh: Link between ownership and financial performance. Corporate Governance-An International Review 15: 1453-68. [CrossRef]

Farooque, Omar Al, Tony van Zijl, Keitha Dunstan, and Wares Karim. 2010. Co-deterministic relationship between ownership concentration and corporate performance-Evidence from an emerging economy. Accounting Research Journal 23: 172-89. [CrossRef]

Fleming, Grant, Richard Heaney, and Rochelle McCosker. 2005. Agency costs and ownership structure in Australia. Pacific-Basin Finance Journal 13: 29-52. [CrossRef]

Florackis, Chrisostomos. 2008. Agency costs and corporate governance mechanisms: Evidence for UK Firms. International Journal of Managerial Finance 4: 37-59. [CrossRef]

Garanina, Tatiana, and Elina Kaikova. 2016. Corporate governance mechanisms and agency costs: Cross-country analysis. Corporate Governance 16: 347-60. [CrossRef]

Henry, Darren. 2010. Agency costs, ownership structure and corporate governance compliance: A private contracting perspective. Pacific-Basin Finance Journal 18: 24-46. [CrossRef]

Himmelberg, Charles P., R. Glenn Hubbard, and Darius Palia. 1999. Understanding the determinants of managerial ownership and the link between ownership and performance. Journal of Financial Economics 53: 353-84. [CrossRef]

Hossain, Mahmud, Andrew K. Prevost, and Ramesh P. Rao. 2001. Corporate governance in New Zealand: The effect of the 1993 Companies Act on the relation between board composition and firm performance. Pacific-Basin Finance Journal 9: 119-45. [CrossRef]

Nguyen, Anh Huu, Duong Thuy Doan, and Linh Ha Nguyen. 2020. Corporate governance and agency cost: Empirical evidence from Vietnam. Journal of Risk and Financial Management 13: 103. [CrossRef]

Ibrahim, Haslindar, and Fazilah M. Abdul Samad. 2011. Corporate governance and agency costs. In International Corporate Governance (Advances in Financial Economics 14). Edited by Kose John and Anil K. Makhija. Bingley: Emerald Group Publishing Limited, pp. 109-30.

ICANZ. 2003. Code of Ethics: Independence in Assurance Engagements. Wellington: ICANZ.

Jensen, Michael C. 1986. Agency costs of free cash flow, corporate finance and takeovers. American Economic Review 76: 323-29.

Jensen, Michael C. 1993. The modern industrial revolution, exit and the failure of internal control system. Journal of Finance 48: 831-80. [CrossRef]

Jensen, Michael C., and William H. Meckling. 1976. Theory of the firm: Managerial behavior, agency costs and ownership structure. Journal of Financial Economics 3: 305-60. [CrossRef]

Khan, Haroon ur Rashid Rashid, Waqas Bin Khidmat, Osama M. Al-Hares, Naeem Muhammad, and Kashif Saleem. 2020. Corporate governance quality, ownership structure, agency costs and firm performance: Evidence from an emerging economy. Journal of Risk and Financial Management 13: 154. [CrossRef]

La Porta, Rafael, Florencio Lopez-de-Silanes, Andrei Shleifer, and Robert W. Vishny. 2000. Investor protection and corporate governance. Journal of Financial Economics 58: 3-27. [CrossRef]

Liu, Huilong, Hong Wang, and Liansheng Wu. 2016. Removing vacant chairs: Does independent directors' attendance at board meetings matter? Journal of Business Ethics 133: 375-93. [CrossRef] 
Mangena, Musa, and Richard Pike. 2005. The effect of audit committee shareholding, financial expertise and size on interim financial disclosures. Accounting and Business Research 35: 327-49. [CrossRef]

McKnight, Phillip J., and Charlie Weir. 2009. Agency costs, corporate governance mechanisms and ownership structure in large UK publicly quoted companies: A panel data analysis. The Quarterly Review of Economics and Finance 49: 139-58. [CrossRef]

Moez, Dabboussi. 2018. Agency costs, corporate governance and the nature of controlling shareholders: Evidence from French listed firms. International Journal of Accounting and Financial Reporting 8: 256-77. [CrossRef]

Noravesh, Eiraj, Gholamreza Karami, and Sani Jalal Vafi. 2009. An investigation on the relationship between corporate governance mechanisms and agency costs among listed firms of Tehran Stock Exchange. Accounting Research 1: 4-27.

O'Callaghan, Steve. 2015. Agency Problems and Ownership Structure in Large Private Firms in the UK. Ph.D. thesis, Bangor University, Bangor, UK.

Opler, Tim, and Sheridan Titman. 1993. The determinants of leveraged buyout activity: Free cash flow vs financial distress costs. Journal of Finance XLVIII: 1985-99.

Persons, Obeua S. 2005. The relation between the new corporate governance rules and the likelihood of financial statement fraud. Review of Accounting and Finance 4: 125-48. [CrossRef]

Rashid, Afzalur. 2015. Revisiting agency theory: Evidence of board independence and agency cost from Bangladesh. Journal of Business Ethics 130: 181-98. [CrossRef]

Rashid, Afzalur. 2016. Managerial ownership and agency cost: Evidence from Bangladesh. Journal of Business Ethics 137: 609-21. [CrossRef]

Shleifer, Andrei, and Robert W. Vishny. 1986. Large shareholders and corporate control. The Journal of Political Economy 4: 461-88. [CrossRef]

Shleifer, Andrei, and Robert W. Vishny. 1997. A survey of corporate governance. Journal of Finance 52: 737-83. [CrossRef]

Singh, Manohar, and Wallace N. Davidson III. 2003. Agency costs, ownership structure and corporate governance mechanisms. Journal of Banking and Finance 27: 793-816. [CrossRef]

Vijayakumaran, Ratnam. 2019. Agency cost, ownership, and internal governance mechanisms: Evidence from Chinese listed companies. Asian Economic and Financial Review 9: 133-54. [CrossRef]

Villalonga, Belen, and Raphael Amit. 2006. How do family ownership, control and management affect firm value? Journal of Financial Economics 80: 385-417. [CrossRef]

Weir, Charlie, David Laing, and Phillip J. McKnight. 2002. Internal and external governance mechanisms: Their impact on the performance of large UK public companies. Journal of Business Finance E Accounting 29: 579-611.

Wellalage, Nirosha Hewa, and Stuart Locke. 2011. Agency costs, ownership structure and corporate governance mechanisms: A case study in New Zealand unlisted small companies. International Research Journal of Finance and Economics 78: 178-92. [CrossRef]

Wintoki, M. Babajide. 2007. Corporate boards and regulation: The effect of the Sarbanes-Oxley Act and the exchange listing requirements on firm value. Journal of Corporate Finance 13: 229-50. [CrossRef]

Xie, Biao, Wallace N. Davidson III, and Peter J. DaDalt. 2003. Earnings management and corporate governance: The role of the board and the audit committee. Journal of Corporate Finance 9: 295-316. [CrossRef] 